\title{
Riverine coupling of biogeochemical cycles between land, oceans, and atmosphere
}

\author{
Anthony K Aufdenkampe ${ }^{1 *}$, Emilio Mayorga ${ }^{2}$, Peter A Raymond ${ }^{3}$, John M Melack ${ }^{4}$, Scott C Doney ${ }^{5}$, \\ Simone R Alin ${ }^{6}$, Rolf E Aalto ${ }^{7}$, and Kyungsoo Yoo $^{8}$
}

\begin{abstract}
Streams, rivers, lakes, and other inland waters are important agents in the coupling of biogeochemical cycles between continents, atmosphere, and oceans. The depiction of these roles in global-scale assessments of carbon $(C)$ and other bioactive elements remains limited, yet recent findings suggest that $C$ discharged to the oceans is only a fraction of that entering rivers from terrestrial ecosystems via soil respiration, leaching, chemical weathering, and physical erosion. Most of this $\mathrm{C}$ influx is returned to the atmosphere from inland waters as carbon dioxide $\left(\mathrm{CO}_{2}\right)$ or buried in sedimentary deposits within impoundments, lakes, floodplains, and other wetlands. Carbon and mineral cycles are coupled by both erosion-deposition processes and chemical weathering, with the latter producing dissolved inorganic $\mathrm{C}$ and carbonate buffering capacity that strongly modulate downstream $\mathrm{pH}$, biological production of calcium-carbonate shells, and $\mathrm{CO}_{2}$ outgassing in rivers, estuaries, and coastal zones. Human activities substantially affect all of these processes.
\end{abstract}

Front Ecol Environ 2011; 9(1): 53-60, doi:10.1890/100014

$\mathbf{R}$ vers and other inland water systems represent distinct ecosystems, geomorphological agents, sites of biogeochemical storage and transformation, and conduits for material transport across continents and to the oceans, and are linked with human health and economic activity (Figures 1 and 2). Although the importance of rivers in modulating the transfer of nutrients from the land to coastal areas has long been recognized (Smith and Hollibaugh 1993), rivers are typically considered as passive "pipes" in regional and global budgets of carbon (C) and weathering products (ie dissolved ions and sediment). Recent studies and syntheses have overturned

\section{In a nutshell:}

- Rivers and other inland waters receive, transport, process, and return to the atmosphere amounts of carbon (C) of similar magnitude to the net ecosystem $\mathrm{C}$ balance of the terrestrial ecosystems in their watersheds

- Burial of $\mathrm{C}$ on continents - within sedimentary deposits of inland waters - is an order of magnitude greater than burial of $\mathrm{C}$ in the oceans

- Human-accelerated chemical weathering of minerals in watersheds affects coastal-zone acidification

${ }^{1}$ Stroud Water Research Center, Avondale, PA *aufdenkampe@ stroudcenter.org); ${ }^{2}$ Applied Physics Laboratory, University of Washington, Seattle, WA; ${ }^{3}$ Yale School of Forestry and Environmental Studies, New Haven, CT; ${ }^{4}$ Bren School of Environmental Science and Management, University of California, Santa Barbara, CA; ${ }^{5}$ Woods Hole Oceanographic Institution, Woods Hole, MA; ${ }^{6}$ Pacific Marine Environmental Laboratory, NOAA, Seattle, WA; ${ }^{7}$ School of Geography, College of Life and Environmental Sciences, University of Exeter, Devon, UK; ${ }^{8}$ Department of Soil, Water and Climate, University of Minnesota, St Paul, MN this view of rivers as passive transporters (Richey et al. 2002; Cole et al. 2007; Battin et al. 2009; Tranvik et al. 2009) and of weathering exports as unresponsive to human impacts (Raymond et al. 2008). A key finding is that the amount of $\mathrm{C}$ that rivers deliver to the oceans is only a fraction of that entering rivers from terrestrial ecosystems (Figure 3). Most of this $\mathrm{C}$ is returned to the atmosphere in the form of carbon dioxide $\left(\mathrm{CO}_{2}\right)$ before reaching the oceans or is stored within river corridors as sedimentary organic carbon (OC) after erosion and transport from distant sites. Understanding the interplay between reactivity, transport, and coupling among landscape components (ie uplands, riparian zones, streams and rivers, wetlands, lakes, floodplains) is a fundamental challenge for characterizing the susceptibility of riverine biogeochemical function to climate and landuse change.

Here we concentrate on three important aspects of water, C, and mineral cycles - linked together - to illustrate the role of rivers and other inland waters as biogeochemical couplers of landscapes and Earth-system components (ie continents, oceans, atmosphere):

(1) The lateral exports of $\mathrm{C}$ from terrestrial ecosystems by streams and subsequent $\mathrm{CO}_{2}$ outgassing to the atmosphere, highlighting their increasingly recognized importance for closing terrestrial net ecosystem C balance (see Panel 1);

(2) The erosion, mixing, and burial of minerals and associated $\mathrm{OC}$, including the coupling of $\mathrm{C}$ sequestration with geomorphological drivers;

(3) The influence of river exports of alkalinity and major ions on coastal responses to ocean acidification, including the effects of human perturbation within watersheds on mineral weathering. 


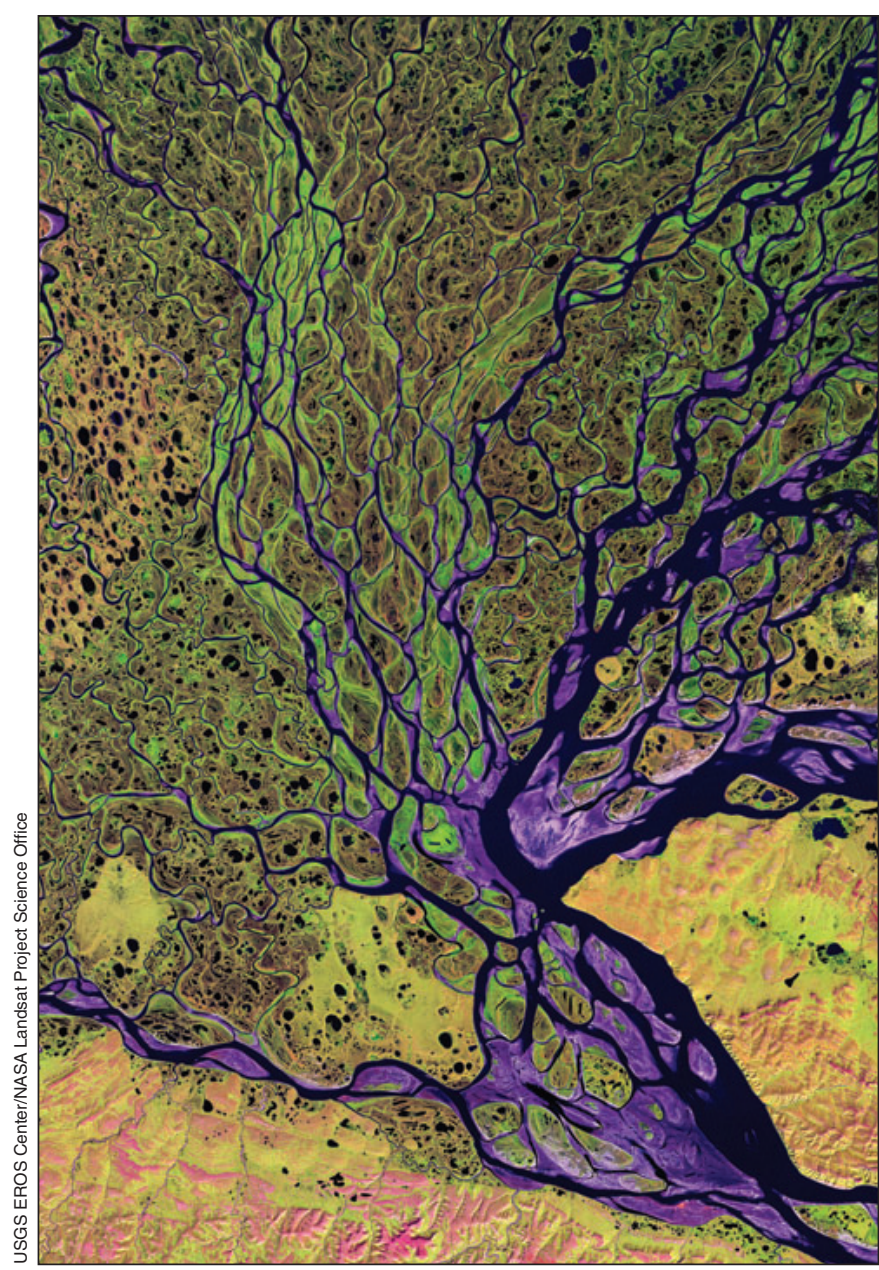

Our consideration of coupling focuses primarily on that between continents, oceans, and atmosphere by rivers and other inland waters. We mainly consider biogeochemical coupling between $\mathrm{C}$ and inorganic species, such as alumino-silicate and carbonate minerals, in the context of geochemical and geomorphological processes, rather than coupling between different bioactive ele-

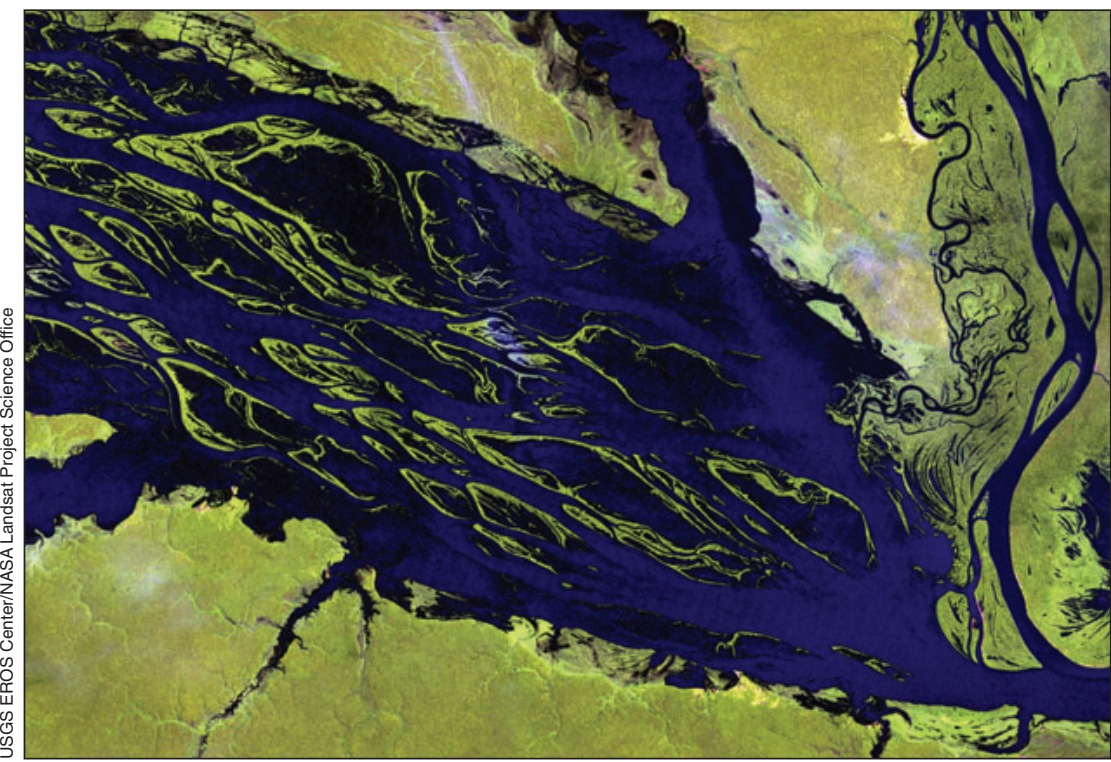

Figure 1. The delta of Russia's Lena River. Terrestrial and aquatic ecosystems closely intermingle in many continental areas across the world, such as boreal ecosystems.

ments (ie $\mathrm{C}$, nitrogen $[\mathrm{N}]$, phosphorus $[\mathrm{P}]$, oxygen $[\mathrm{O}]$, and sulfur [S]), which we assume to be implicit in our discussion of $\mathrm{C}$ processing. Also, we consider most inland waters - such as streams, lakes, impoundments, and the many types of wetlands - as being components of river systems. Although each of these inland water types represents a distinct ecosystem with associated processes, nearly all receive and/or discharge materials from/to the river networks to which they are coupled.

\section{From land to river to atmosphere: $\mathrm{C}$ under the radar}

In the early 1990s, a decade's worth of oceanographic and global C modeling identified a significant "missing carbon sink" on continents that was equivalent to about onethird of global fossil-fuel emissions, launching numerous research efforts to quantify the net storage of $\mathrm{C}$ in the major terrestrial ecosystems. Nearly two decades later, a consensus has yet to emerge regarding the spatial distribution of terrestrial $\mathrm{C}$ sinks. One roadblock is that net ecosystem production (NEP) measured at local scales does not often extrapolate well to larger scales (Ometto et al. 2005; Stephens et al. 2007). These discrepancies may be due to the assumption that all NEP is converted entirely to storage, without consideration of lateral export (Panel $1)$. Recent findings suggest that, in many cases, lateral exports - through rivers, airborne transport of reduced C compounds, and commercial trade in food and forest products - can be of equal magnitude to storage fluxes (Richey et al. 2002; Billett et al. 2004; Ciais et al. 2008). This observation may help reconcile disparate estimates of $\mathrm{C}$ sequestration and provide improved estimates of terrestrial NEP (Billett et al. 2004; Cole et al. 2007).

Aquatic biogeochemists have established that nearly all fresh waters contain $\mathrm{CO}_{2}$ in concentrations that are supersaturated with respect to that of the atmosphere. The partial pressure of dissolved $\mathrm{CO}_{2}\left(\mathrm{pCO}_{2}\right.$; Panel 2) in water in equilibrium with the atmosphere is equivalent to the concentration of $\mathrm{CO}_{2}$ in the atmosphere, which is currently about 390 parts per million (ppm) by volume. Measured $\mathrm{pCO}_{2}$ values typically range from 1000 to more than 12000 ppm in rivers (Cole and Caraco 2001; Richey et al. 2002; Johnson et al. 2008; Humborg et al. 2010) and from 350

Figure 2. The Negro River in the central Amazon, just upstream of the confluence with the Branco River. River floodplains and inland waters are dynamic systems that link Earth systems across large spatial and temporal scales. 
to more than $10000 \mathrm{ppm}$ in lakes and reservoirs (Sobek et al. 2005; Marotta et al. 2009) - with tropical waters typically exhibiting higher concentrations of $\mathrm{CO}_{2}$ than temperate waters, and rivers and wetlands typically having higher concentrations of $\mathrm{CO}_{2}$ than lakes (Table 1). These values show large net freshwater-to-atmosphere $\mathrm{CO}_{2}$ fluxes, which must be balanced by substantial inputs from terrestrial systems, as either $\mathrm{OC}$ or $\mathrm{CO}_{2}$-rich groundwater (Mayorga et al. 2005; Johnson et al. 2008). The translation of water-air $\mathrm{CO}_{2}$ gradients to areal fluxes requires multiplication by gas exchange velocities $(k)$, which vary as a function of turbulence in the surface water and, to a lesser degree, with temperature (Table 1 and WebPanel 1). The $\mathrm{CO}_{2}$ fluxes from one square meter of surface water can therefore be much higher than $\mathrm{CO}_{2}$ fluxes into one square meter of the adjacent terrestrial ecosystem (Table 1 ).

Regional and global estimates of $\mathrm{CO}_{2}$ outgassing fluxes rely as much on estimates of inland water area as on the $\mathrm{CO}_{2}$ fluxes per unit area of surface water. Over the past few years, our estimation of inland water area has substantially increased as a result of (1) improvements in remote-sensing approaches, often combining data captured from multiple airborne- and satellite-borne sensors to assess flooding beneath vegetation (Hess et al. 2003; Prigent et al. 2007), and (2) compilations and algorithms to estimate areal coverage of water bodies (Lehner and Döll 2004; Downing 2009). Recent studies have more than doubled the global land area known to be seasonally to permanently inundated to over 20 million $\mathrm{km}^{2}$ (Lehner and Döll 2004; Downing 2009), an area roughly equivalent to $15 \%$ of global land surfaces, excluding Antarctica and Greenland (Table 1). These improved estimates of inundated area translate to proportional increases in the magni-

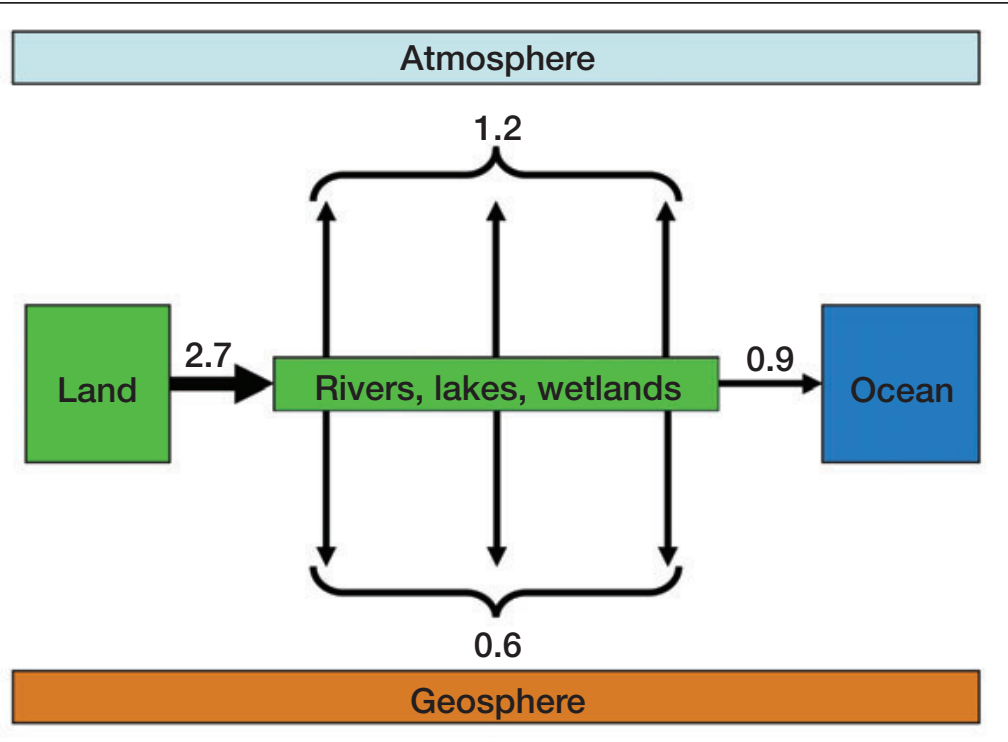

Figure 3. The coupling of land, oceans, and atmosphere by rivers, lakes, and wetlands. All numbers are fluxes in units of $\mathrm{PgC} \mathrm{yr}^{-1}$, with values based on an analysis by Battin et al. (2009); accumulation fluxes within both land and ocean each equal $2.2 \mathrm{Pg} \mathrm{C} \mathrm{yr}^{-1}$. The $\mathrm{CO}_{2}$ outgassing and continental burial fluxes from Battin et al. (2009) are substantially larger than those published by Cole et al. (2007), primarily on account of more complete consideration of high-latitude lakes. A more balanced inclusion of tropical waters and wetlands, and temperature dependencies on $\mathrm{pCO}_{2}$ and $\mathrm{k}$, as we consider in Table 1, would require a further increase in outgassing fluxes to the atmosphere. These flux values have direct consequences to net $\mathrm{C}$ balances on land because of the need to balance the global $\mathrm{C}$ budget.

tudes of outgassing fluxes.

Published estimates of the global flux of $\mathrm{CO}_{2}$ outgassing from inland surface waters range from 0.75 to 1.4 petagrams of $\mathrm{C}$ per year $\left(\mathrm{Pg} \mathrm{C} \mathrm{yr}^{-1}\right.$; Figure 3$)$, which is globally important when compared with estimates of net $\mathrm{C}$ accumulation on continents $\left(2.2 \mathrm{Pg} \mathrm{C} \mathrm{yr}^{-1}\right)$ or in the oceans (2.2 $\mathrm{Pg} \mathrm{C} \mathrm{yr}^{-1}$; Cole and Caraco 2001; Cole et al. 2007; Battin et al. 2009; Takahashi et al. 2009; Tranvik et al. 2009). Yet these $\mathrm{CO}_{2}$ fluxes from inland waters directly to the atmosphere are rarely considered in global or regional

\section{Panel 1. Terms of terrestrial ecosystem carbon budgeting}

Net ecosystem production (NEP) is the difference between gross primary production and the community respiration of an ecosystem, typically reported in units of $C$ per unit time per unit area. NEP represents the amount of $C$ available for storage or export over a given time interval, with a positive value for net autotrophic ecosystems and a negative value for net heterotrophic ecosystems. Although a fundamental property of an ecosystem, NEP is challenging to measure over annual and decadal time scales. The historical approach for terrestrial ecosystems has been to measure changes in $\mathrm{C}$ stocks in biomass and soils over many years, with the implicit assumption that lateral $\mathrm{C}$ export is negligible. A more recent approach has been to deploy sensors for $\mathrm{CO}_{2}$ and wind on a tower - emerging from the forest canopy - to take measurements of the turbulent vertical fluxes of $\mathrm{CO}_{2}$ every few seconds for a period of years. Data from these "eddy covariance flux" towers are integrated to quantify the net amount of $\mathrm{CO}_{2}$ transported into the forest from the atmosphere, which is known as net ecosystem exchange (NEE, where $\mathrm{NEE}<0$ represents a land sink for $\mathrm{CO}_{2}$ ). The assumption has been that lateral export is negligible and that NEE equals NEP, but several new studies have called into question these assumptions and assert that lateral export of C from terrestrial ecosystems - via rivers and other processes - may be substantial relative to NEP or NEE (Richey et al. 2002; Billett et al. 2004; Cole et al. 2007; Ciais et al. 2008). As a result, an effort has been made to remind the terrestrial ecosystem research community of the original definition of NEP, which includes export (Lovett et al. 2006), and to introduce a less ambiguous term, net ecosystem carbon balance (NECB), to describe only the flux of C available for local storage (Chapin et al. 2006). 


\section{Panel 2. Dissolved carbon dioxide, explained}

Dissolved carbon dioxide $\left(\mathrm{CO}_{2}\right)$, carbonic acid $\left(\mathrm{H}_{2} \mathrm{CO}_{3}\right)$, bicarbonate $\left(\mathrm{HCO}_{3}{ }^{-}\right)$, and carbonate $\left(\mathrm{CO}_{3}{ }^{2-}\right)$ are collectively referred to as dissolved inorganic carbon (DIC). These chemical species readily interconvert from one to another as a function of their relative concentrations, $\mathrm{pH}$, temperature, and the concentrations of other buffering and complexing species. With a gas species $\left(\mathrm{CO}_{2}\right)$ at one end of the reaction chain and several mineral species at the other (eg calcium carbonate, $\mathrm{CaCO}_{3}$ ), the carbonate buffering system - as this series of related reactions is known - can only be understood by simultaneously solving a series of thermodynamic equations. The carbonate buffering system is further coupled to mineral cycles because carbonate alkalinity $\left(\mathrm{Carb}_{\text {alk }}=\left[\mathrm{HCO}_{3}{ }^{-}\right]+2 \times\left[\mathrm{CO}_{3}{ }^{2}\right]\right)$ is controlled by the thermodynamic requirement to balance the electrostatic charge imbalance between strong base cations (eg calcium $\left[\mathrm{Ca}^{2+}\right]$, manganese $\left[\mathrm{Mg}^{2+}\right]$, sodium $\left[\mathrm{Na}^{+}\right]$, potassium $\left[\mathrm{K}^{+}\right]$) and strong acid anions (eg chlorine $\left[\mathrm{Cl}^{-}\right]$, sulfate $\left[\mathrm{SO}_{4}{ }^{2-}\right]$ ) that is created during the chemical weathering of minerals. These equations and associated thermodynamic constants have been thoroughly studied (Dickson et al. 2007).

Concentrations of dissolved "free" $\mathrm{CO}_{2}$ are often reported in terms of partial pressure, $\mathrm{pCO}_{2}$, which is the equivalent atmospheric $\mathrm{CO}_{2}$ concentration that would be in equilibrium with the water sample. Typical $\mathrm{pCO}_{2}$ units are parts per million (ppm) volume of $\mathrm{CO}_{2}$ per volume of air, or microatmospheres ( $\mu$ atm). Thus, $\mathrm{pCO}_{2}$ does not directly refer to a concentration of free $\mathrm{CO}_{2}$ in water but rather the result of the application of Henry's Law of gas dissolution equilibrium, which simply states that at a given temperature the concentration of a dissolved gas is proportional to the partial pressure of that gas in equilibrium with the solution.

C balances. Furthermore, recent re-evaluations of the factors used to generate regional $\mathrm{CO}_{2}$ outgassing estimates $-\mathrm{pCO}_{2}$ concentrations, $k$, and areal extent of inundation - along with a more balanced consideration of the tropics and wetlands all support an increase to published values for regional and global $\mathrm{CO}_{2}$ outgassing fluxes (Table 1 and WebPanel 1). Such estimates would have direct consequences on net $\mathrm{C}$ balances on land because of the need to balance global, regional, and even local C budgets.

The effort to quantify the net $\mathrm{C}$ sink in mature rainforests in the Amazon Basin is an excellent case study, demonstrating the importance of rivers in coupling terrestrial and atmospheric C cycles (Richey et al. 2002; Ometto et al. 2005). Net ecosystem exchange (NEE; Panel 1) of $\mathrm{C}-$ measured by eddy covariance flux towers situated throughout the Amazon Basin - has ranged from high forest sinks to modest sources ( -6 to +1 megagrams [Mg] C ha ${ }^{-1} \mathrm{yr}^{-1}$; Ometto et al. 2005), yet biomass and soil surveys generally yield lower sink estimates (Ometto et al. 2005; Chave et al. 2008). Richey et al. (2002) suggested that lateral $\mathrm{C}$ exports to streams could play a potential role in balancing this discrepancy. In response, two studies examined whether lateral stream exports might be important relative to terrestrial fluxes (Waterloo et al. 2006; Johnson et al. 2008). For streams in the seasonally dry southern Amazon, a net export of $0.40 \mathrm{Mg} \mathrm{C} \mathrm{ha}^{-1} \mathrm{yr}^{-1}$ was calculated (Johnson et al. 2008) for dissolved $\mathrm{CO}_{2}$, which is largely outgassed within the few hundred meters downstream of groundwater seeps or springs, representing one-half of total deep-soil respiration; Johnson et al. (2008) also estimated that an additional $0.10 \mathrm{Mg} \mathrm{C} \mathrm{ha}^{-1}$ $\mathrm{yr}^{-1}$ was exported as dissolved organic carbon (DOC). Because no eddy covariance tower was present at the sites studied by Johnson et al. (2008), comparisons with published Amazon NEE values from other sites led us to estimate that stream export of groundwater $\mathrm{CO}_{2}$ and $\mathrm{DOC}$ could account for $10-100 \%$ of NEE at that site (Ometto et al. 2005; Johnson et al. 2008). Waterloo et al. (2006) measured DOC and particulate organic carbon (POC) exports in a 2nd- to 3rdorder blackwater stream within an eddy covariance tower site, and estimated 0.19 $\mathrm{Mg} \mathrm{Cha}{ }^{-1} \mathrm{yr}^{-1}$ of $\mathrm{OC}$ export to represent $5-6 \%$ of NEE. This estimate does not include dissolved $\mathrm{CO}_{2}$, yet our few measurements of $\mathrm{CO}_{2}$ degassing from these highly acidic streams immediately upstream of Waterloo et al.'s (2006) OC monitoring site are as high as, or even higher than, those of Johnson et al. (2008), suggesting that $>15 \%$ of NEE may be exported as dissolved $\mathrm{CO}_{2}$ and OC (Aufdenkampe unpublished). Neither study was able to compare local NEE measurements with the full suite of stream $\mathrm{C}$ exports, including DOC, POC, and total dissolved inorganic carbon (DIC, which includes $\mathrm{CO}_{2}$; Panel 2). Nevertheless, in a peatland system in Scotland, Billett et al. (2004) were able to account for all lateral $\mathrm{C}$ exports via streams within the footprint of an eddy covariance tower and demonstrated that NEE changed from a net sink of $0.278 \mathrm{Mg} \mathrm{C} \mathrm{ha}^{-1} \mathrm{yr}^{-1}$ to a net source of $0.083 \mathrm{Mg} \mathrm{C} \mathrm{ha} \mathrm{yr}^{-1}$ when lateral stream fluxes were considered. One challenge, however, of comparing stream $\mathrm{C}$ exports with NEE is whether the evaded $\mathrm{CO}_{2}$ (from groundwater or respired from organic matter) is already captured within the footprint of the eddy covariance tower. Regardless, these studies suggest that lateral transport of $\mathrm{C}$ by streams should be considered when evaluating net ecosystem carbon balance (Chapin et al. 2006).

\section{Carbon sequestration from soils to sea: erosion is key}

Geologists and oceanographers have long hypothesized that there is a connection between tectonic uplift, mineral erosion, $\mathrm{C}$ burial, and atmospheric oxygen over geological time scales (Berner 1989), with river systems implicitly coupling the biogeochemical cycles between continents, oceans, and atmosphere. Studies of OC turnover in soils and sediments have begun to describe the mechanisms for the coupling of mineral and biogeochemical cycles via organo-mineral complexation, which is a critical factor in stabilizing OC (Hedges and Keil 1995). Yet OC and mineral production are typically spatially separated. Biological 
primary production mainly occurs where there is light that is, above the soil surface or in the low-turbidity euphotic zone of lakes and oceans. Mineral surfaces are produced at the bedrock-soil interface and subsoil, where primary minerals are chemically weathered to secondary alumino-silicate clays and iron and aluminum hydroxides. In most systems, the flux of OC mobilized into river corridors and the coastal oceans is substantially greater than the system's capacity to stabilize it via organo-mineral complexation, burial into anoxic environments, or other mechanisms. Thus, most OC is rapidly metabolized or photolysed and returned to the atmosphere as $\mathrm{CO}_{2}$ (Cole et al. 2007). Therefore, the rate of erosion, delivery, and mixing of fresh mineral surfaces with fresh organic matter could likely control watershed- to global-scale $\mathrm{C}$ sequestration fluxes over both current and geological time scales (Hedges 2002; Kennedy et al. 2006).

A series of reports and letters responding to Van Oost et al. (2007) serves to highlight an ongoing debate over whether anthropogenic erosion might result in a globally important C sink (Stallard 1998), an important net $\mathrm{CO}_{2}$ source (Lal 2003), or a combination that yields a slight net sink (Van Oost et al. 2007). Previous studies have explicitly considered one or more of three mechanisms linking erosion-deposition processes to alterations of net $\mathrm{CO}_{2}$ fluxes between the land and the atmosphere: (1) complete to partial replacement of soil OC at eroding agricultural sites via crop production (Stallard 1998); (2) burial and inhibited decomposition of OC eroded from topsoils
(Stallard 1998); and (3) enhanced decomposition of soil OC due to the breakdown of protective soil structures during erosion and transport (Lal 2003). Nevertheless, these studies did not consider a fourth mechanism that could substantially augment estimates of global $\mathrm{C}$ sequestration due to erosion: (4) the transport of OC-poor minerals from deep soil horizons into environments where stable Cmineral complexes are formed with otherwise fresh, reactive C (Aufdenkampe et al. unpublished).

The conventional scientific perspective is that, globally, rivers discharge about $0.4 \mathrm{Pg} \mathrm{C} \mathrm{yr}^{-1}$ as $\mathrm{OC}$ to the oceans, with about one-half in the form of DOC and onehalf as POC, and an additional 0.5 to 0.4 $\mathrm{Pg} \mathrm{C} \mathrm{yr}^{-1}$ as DIC (Schlünz and Schneider 2000; Figure 3). These estimates have changed surprisingly little over time, despite revisions to both sediment delivery fluxes and the concentrations of POC associated with those sediments (Berner 1989; Schlünz and Schneider 2000). Geomorphologists have known, however, that only $5-25 \%$ of eroded sediment actually reaches the oceans, with most being deposited at the bottom of hillslopes (ie colluvium), in floodplains and wetlands (ie alluvium), and in reservoirs, lakes, and estuaries (Figure 4). This is apparent when comparing recent global estimates of modern fluxes of 12.6 $\mathrm{Pg} \mathrm{yr}^{-1}$ of sediment delivered to the oceans (Syvitski et al. 2005) with estimates of modern erosion fluxes of 50-150 Pg yr ${ }^{-1}$ of soil (Stallard 1998; Wilkinson and McElroy 2007). Conservatively assuming that the OC content of these sediments averages $1 \%$, then about

\begin{tabular}{|c|c|c|c|c|c|}
\hline \multirow[t]{2}{*}{ Zone-class } & $\begin{array}{l}\text { Area of inland waters } \\
\quad\left(1000 \mathrm{~km}^{2}\right)\end{array}$ & \multirow{2}{*}{$\begin{array}{l}\mathrm{pCO}_{2} \\
(\mathrm{ppm}) \\
\text { median }\end{array}$} & \multirow{2}{*}{$\begin{array}{c}\text { Gas exchange velocity } \\
\left(\mathrm{k}_{600}, \mathrm{~cm} \mathrm{hr}^{-1}\right) \\
\text { median }\end{array}$} & \multirow{2}{*}{$\begin{array}{c}\text { Areal outgassing } \\
\left(\mathrm{g} C \mathrm{~m}^{-2} \mathrm{yr}^{-1}\right) \\
\text { median }\end{array}$} & \multirow{2}{*}{$\begin{array}{c}\begin{array}{c}\text { Zonal outgassing } \\
\left(\mathrm{PgC} C \mathrm{yr}^{-1}\right)\end{array} \\
\text { median }\end{array}$} \\
\hline & $\min -\max$ & & & & \\
\hline \multicolumn{6}{|l|}{ Tropical $\left(0^{\circ}-25^{\circ}\right)$} \\
\hline Lakes and reservoirs & $1840-1840$ & 1900 & 4.0 & 240 & 0.45 \\
\hline Rivers (>60-100 m wide) & $|46-| 46$ & 3600 & 12.3 & 1600 & 0.23 \\
\hline Streams (<60-100 m wide) & $60-60$ & 4300 & 17.2 & 2720 & 0.16 \\
\hline Wetlands & $3080-6170$ & 2900 & 2.4 & 240 & 1.12 \\
\hline \multicolumn{6}{|l|}{ Temperate $\left(25^{\circ}-50^{\circ}\right)$} \\
\hline Lakes and reservoirs & $880-1050$ & 900 & 4.0 & 80 & 0.08 \\
\hline Rivers (>60-100 m wide) & $70-84$ & 3200 & 6.0 & 720 & 0.05 \\
\hline Streams (<60-100 m wide) & $29-34$ & 3500 & 20.2 & 2630 & 0.08 \\
\hline Wetlands & $880-3530$ & 2500 & 2.4 & 210 & 0.47 \\
\hline \multicolumn{6}{|l|}{ Boreal and Arctic $\left(50^{\circ}-90^{\circ}\right)$} \\
\hline Lakes and reservoirs & $80-1650$ & 1100 & 4.0 & 130 & 0.11 \\
\hline Rivers (>60-100 m wide) & $7-131$ & 1300 & 6.0 & 260 & 0.02 \\
\hline Streams (<60-100 m wide) & $3-54$ & 1300 & 13.1 & 560 & 0.02 \\
\hline Wetlands & $280-5520$ & 2000 & 2.4 & 170 & 0.49 \\
\hline Global & \multicolumn{3}{|c|}{ Percent of global land area } & & \\
\hline Lakes and reservoirs & $2800-4540$ & $2.1 \%-3.4 \%$ & & & 0.64 \\
\hline Rivers (>60-100 m wide) & $220-360$ & $0.2 \%-0.3 \%$ & & & 0.30 \\
\hline Streams (<60-100 m wide) & $90-150$ & $0.1 \%-0.1 \%$ & & & 0.26 \\
\hline Wetlands & $4240-15220$ & $3.2 \%-11.4 \%$ & & & 2.08 \\
\hline All inland waters & $7350-20260$ & $5.5 \%-15.2 \%$ & & & 3.28 \\
\hline Notes: see WebPanel I for associated $r$ & references. & & & & \\
\hline
\end{tabular}




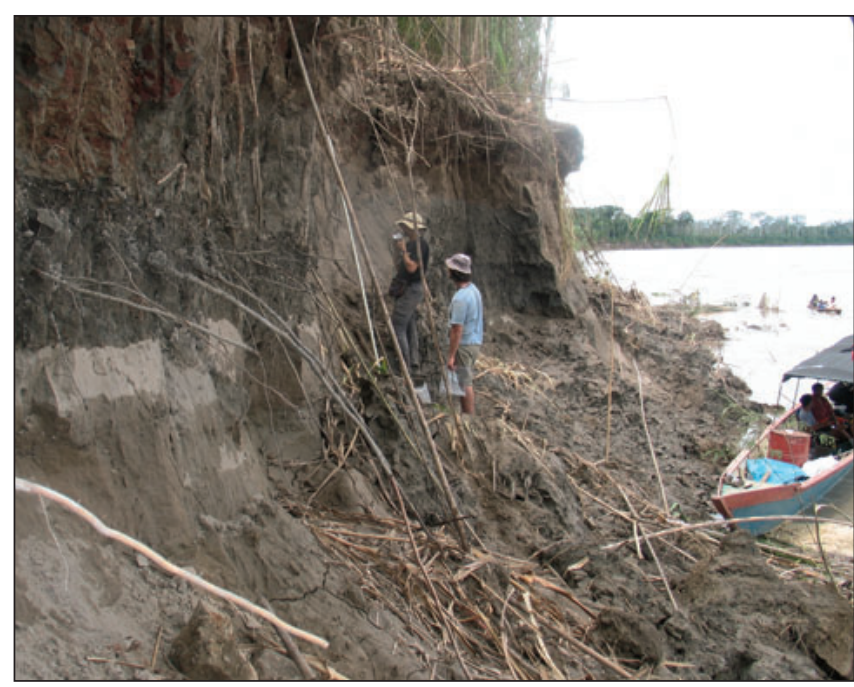

Figure 4. A typical floodplain deposit exposed at a cutbank on the Ucayali River, which drains the Peruvian Andes to form the Amazon River. Depositional events can lay down 20 to $\geq 100 \mathrm{~cm}$ of sediment in a few days, burying a forest floor that may have developed over decades, as shown here. Average annual deposition rates for these floodplains can exceed $5 \mathrm{~cm} \mathrm{yr}^{-1}$ (Aalto et al. 2003). Such dynamic floodplain environments are common around the world in foreland basins, which are mid-continent depressions that continuously generate sediment accommodation space as uplifting mountain belts depress adjacent continental plates.

0.5-1.5 $\mathrm{Pg} \mathrm{C} \mathrm{yr}^{-1}$ is buried with those sediments in continental settings before reaching the oceans. These values match the 0.6-1.6 $\mathrm{Pg} \mathrm{C} \mathrm{yr}^{-1}$ that Stallard (1998) estimated is buried as a result of anthropogenic erosion alone. The low end of these values matches the $0.6 \mathrm{Pg} \mathrm{C}$ $\mathrm{yr}^{-1}$ burial flux for lakes and impoundments that Tranvik et al. (2009) estimated from extrapolating areal C burial fluxes (Figure 3). However, Tranvik et al. (2009) did not consider floodplains, wetlands, or colluvium.

Multiple lines of evidence (described above) suggest that an order of magnitude more $\mathrm{C}$ is buried annually in stable continental deposits than is buried within sediments in the world's oceans, and most of this $\mathrm{C}$ burial on continents is driven by human-induced erosion (Stallard 1998; Wilkinson and McElroy 2007). Critically, these C fluxes - which are substantial relative to global and regional net terrestrial ecosystem $\mathrm{C}$ balance - are sensitive to future climate and land-use change.

\section{Mineral weathering and the coastal buffering system: can human activities on continents affect coastal acidification?}

Rising atmospheric $\mathrm{CO}_{2}$ and other global changes are altering the acid/base chemistry and carbonate buffering system of estuaries and coastal systems (Andersson et al. 2005; Doney et al. 2009). As for the open ocean, rising atmospheric $\mathrm{CO}_{2}$ due to human activities increases seawater $\mathrm{pCO}_{2}$ concentrations by air-water gas exchange. The additional dissolved $\mathrm{CO}_{2}$ combines with water to form carbonic acid $\left(\mathrm{H}_{2} \mathrm{CO}_{3}\right)$, which can then dissociate into bicarbonate $\left(\mathrm{HCO}_{3}^{-}\right)$and hydrogen $\left(\mathrm{H}^{+}\right)$ions, the latter leading to a reduction in $\mathrm{pH}$ (Panel 2). The resulting suite of chemical changes - often termed ocean acidification - also includes a reduction in the carbonate ion $\left(\mathrm{CO}_{3}{ }^{2-}\right)$ concentration, which tends to increase the solubility of calcium-carbonate $\left(\mathrm{CaCO}_{3}\right)$ minerals such as aragonite and calcite, which are used by many organisms to build shells and skeletons.

The acid/base chemistry of estuaries and coastal ecosystems is particularly susceptible to global change because of additional water, solute, and sediment inputs from the continents and because the buffering capacities in such ecosystems are typically lower than those in the open ocean. Processes such as riverine freshwater inputs, acid rain, atmospheric dry deposition, sediment denitrification, anaerobic organic matter decomposition, and submarine groundwater discharge all have large impacts on the coastal inorganic $\mathrm{C}$ system (Doney et al. 2007; Fennel et al. 2008; Thomas et al. 2009; Borges and Gypens 2010). Most of these processes are susceptible to anthropogenic forcing, and coastal ecosystems are particularly sensitive to higher $\mathrm{pCO}_{2}$. Seagrasses and some types of phytoplankton exhibit higher rates of photosynthesis under elevated aqueous $\mathrm{CO}_{2}$, and other organisms may be sensitive to altered $\mathrm{pH}$, particularly at the larval and juvenile stages (Waldbusser et al. 2010). Measuring and assessing these changes in water chemistry is difficult, however, because of the dynamic nature of coastal systems and the limited historical observations that are available for many locations. Estuarine and coastal waters often feature substantial spatial and temporal variability in $\mathrm{pH}$ and $\mathrm{CO}_{2}$ due to physical processes (eg tides, mixing, turbulence, currents) and biogeochemical $\mathrm{C}$ metabolism (eg photosynthesis, respiration, calcification, dissolution).

Changes in riverine chemistry and discharge often play a larger role than local processes in most estuarine and many other coastal systems, and can either offset or accelerate coastal acidification. Enhanced delivery of watershed nutrients and the resulting eutrophication can alter coastal $\mathrm{CO}_{2}$ concentrations (Borges and Gypens 2010). Agricultural (Oh and Raymond 2006), mining (Brake et al. 2001; Raymond and Oh 2009), and urban/suburban practices (Barnes and Raymond 2009) have been linked to direct changes in the delivery of buffering capacity to streams and rivers. These changes have the potential to alter the concentrations of inorganic $\mathrm{C}$ species expected through mixing of fresh water and seawater.

In North America, the Mississippi and Susquehanna rivers have both experienced large changes in carbonate alkalinity $\left(\mathrm{Carb}_{\text {alk }}=\left[\mathrm{HCO}_{3}{ }^{-}\right]+2 \times\left[\mathrm{CO}_{3}{ }^{2-}\right]\right.$; Panel 2) concentrations over the past century (Raymond et al. 2008; Raymond and Oh 2009). These two rivers and their estuaries offer an example of how differences in the chemistry and anthropogenic pressures of watersheds can lead to contrasting coastal ocean responses (Figure 5). The Mississippi River has experienced a $25 \%$ increase in Carb ${ }_{\text {alk }}$ over the past 60 years, accompanied by no change 
in $\mathrm{pH}$; this has resulted in a potential modest increase in both $\mathrm{pCO}_{2}$ and aragonite saturation state $\left(\Omega_{\mathrm{arg}}\right)$ in adjacent coastal waters $\left(\Omega_{\text {arg }}\right.$ is the stability of aragonite mineral, where $\Omega_{\text {arg }}<1$ indicates that the solution is undersaturated and dissolution can occur; Figure 5). The combination of stable $\mathrm{pH}$ and increasing $\mathrm{pCO}_{2}$ are likely due to greater respiration of $\mathrm{OC}$ to $\mathrm{CO}_{2}$ within river waters, which may indicate that inputs of labile OC are now also higher upstream as a result of eutrophication. Increasing $\Omega_{\text {arg }}$ reflects decreasing solubility, and a value of 1 marks the threshold between unsaturated and saturated conditions. In contrast, the Susquehanna River was acidic during the early 1940s on account of discharges from local mining operations, with a theoretical $\Omega_{\text {arg }}<1$ throughout most of Chesapeake Bay to which it drains, which has a salinity below 15 parts per thousand during much of the year (Pritchard 1952; Figure 5). With the abandonment of mining in the watershed, $\Omega_{\text {arg }}$ of Chesapeake Bay has recovered, presumably close to pre-mining levels, and $\mathrm{pCO}_{2}$ concentrations are now much lower than those observed historically.

With respect to future changes and other watersheds, how anthropogenic watershed disturbance alters the $\mathrm{CaCO}_{3}$ saturation state and carbonate chemistry at a given salinity is dependent on the changes in the riverine fluxes of $\mathrm{Ca}^{2+}$, $\mathrm{Carb}_{\mathrm{alk}}$, and DIC, as well as the initial ratios of $\mathrm{Carb}_{\mathrm{alk}}$ :DIC and $\mathrm{Ca}^{2+}: \mathrm{CO}_{3}{ }^{2-}$. Alterations in watershed hydrology are a primary determinant of these fluxes, and future changes are expected as a consequence of global warming. For instance, the Mississippi River now exports $\sim 45 \%$ more Carb alk $_{\text {an }}$ than it did historically, partly as a result of an acceleration of the hydrological cycle (Raymond et al. 2008), which currently offsets a portion of regional coastal acidification. Human land-use patterns are also substantially changing river loadings of nutrients, particulate and dissolved organic matter, and sediments, all of which will influence coastal ocean biogeochemistry. Interactions between river chemistry alterations, climate change, expansion of low-dissolved-oxygen zones, and ocean acidification are poorly defined, and the impact of these multiple stressors on coastal ecosystems is a major research challenge for the future (Doney 2010).

\section{Conclusion}

Terrestrial ecologists and global C modelers alike will benefit from considering the coupling of the Earth's systems by rivers and other inland waters. The old rule of thumb that "rivers export $1 \%$ of terrestrial GPP [gross primary production]" might well be replaced by a new one: "rivers receive, transport, and process the equivalent of terrestrial NEP in their watersheds".

\section{Acknowledgements}

We thank J Cole for encouraging this paper and M Pace for the open dialogue and excellent suggestions for revisions. The US National Science Foundation (NSF) and the National Oceanographic and Atmospheric Administration (NOAA) provided funding for this work.

\section{References}

Aalto R, Maurice-Bourgoin L, Dunne T, et al. 2003. Episodic sediment accumulation on Amazonian flood plains influenced by El Niño/Southern Oscillation. Nature 425: 493-97.

Andersson AJ, Mackenzie FT, and Lerman A. 2005. Coastal ocean and carbonate systems in the high $\mathrm{CO}_{2}$ world of the anthropocene. Am J Sci 305: 875-918.

Barnes RT and Raymond PA. 2009. The contribution of agricultrual and urban activities to inorganic carbon fluxes within temperate watersheds. Chem Geol 266: 327-36.

Bates NR and Hansell DA. 1999. A high resolution study of surface layer hydrographic and biogeochemical properties between Chesapeake Bay and Bermuda. Mar Chem 67: 1-16.

Battin TJ, Luyssaert S, Kaplan LA, et al. 2009. The boundless carbon cycle. Nat Geosci 2: 598-600.

Berner RA. 1989. Biogeochemical cycles of carbon and sulphur and their effect on atmospheric oxygen over Phanerozoic time. Palaeogeogr Palaeoclimatol Palaeoecol 75: 97-122. 
Billett MF, Palmer SM, Hope D, et al. 2004. Linking land-atmosphere-stream carbon fluxes in a lowland peatland system. Global Biogeochem Cy 18: GB1024, doi:10.1029/2003GB002058.

Borges AV and Gypens N. 2010. Carbonate chemistry in the coastal zone responds more strongly to eutrophication than to ocean acidification. Limnol Oceanogr 55: 346-53.

Brake SS, Connors KA, and Romberger SB. 2001. A river runs through it: impact of acid mine drainage on the geochemistry of West Little Sugar Creek pre- and post-reclamation at the Green Valley Coal Mine, Indiana, USA. Environ Geol 40: 1471-81.

Cai W-J. 2003. Riverine inorganic carbon flux and rate of biological uptake in the Mississippi River plume. Geophys Res Lett 30: 1032, doi:10.1029/2002GL016312.

Chapin III FS, Woodwell GM, Randerson JT, et al. 2006. Reconciling carbon-cycle concepts, terminology, and methods. Ecosystems 9: 1041-50.

Chave JRM, Condit R, Muller-Landau HC, et al. 2008. Assessing evidence for a pervasive alteration in tropical tree communities. PLoS Biol 6: e45.

Ciais P, Borges A, Abril G, et al. 2008. The impact of lateral carbon fluxes on the European carbon balance. Biogeosciences 5: 1259-71.

Cole JJ and Caraco NF. 2001. Carbon in catchments: connecting terrestrial carbon losses with aquatic metabolism. Mar Freshwater Res 52: 101-10.

Cole JJ, Prairie YT, Caraco NF, et al. 2007. Plumbing the global carbon cycle: integrating inland waters into the terrestrial carbon budget. Ecosystems 10: 172-85.

Dickson AG, Sabine CL, and Christian JR (Eds). 2007. Guide to best practices for ocean $\mathrm{CO}_{2}$ measurements: PICES Special Publication 3. Sidney, Canada: PICES.

Doney SC. 2010. The growing human footprint on coastal and open-ocean biogeochemistry. Science 328: 1512-16.

Doney SC, Fabry VJ, Feely RA, and Kleypas JA. 2009. Ocean acidification: the other $\mathrm{CO}_{2}$ problem. Annu Rev Mar Sci 1: 169-92.

Doney SC, Mahowald N, Lima I, et al. 2007. Impact of anthropogenic atmospheric nitrogen and sulfur deposition on ocean acidification and the inorganic carbon system. P Natl Acad Sci USA 104: 14580-85.

Downing JA. 2009. Global limnology: up-scaling aquatic services and processes to planet Earth. Verh Internat Verein Limnol 30: 1149-66.

Fennel K, Wilkin J, Previdi M, and Najjar R. 2008. Denitrification effects on air-sea $\mathrm{CO}_{2}$ flux in the coastal ocean: simulations for the northwest North Atlantic. Geophys Res Lett 35: L24608, doi:10.1029/2008gl036147.

Hedges JI. 2002. Sedimentary organic matter preservation and atmospheric $\mathrm{O}_{2}$ regulation. In: Gianguzza A, Pelizzetti E, and Sammartano S (Eds). Chemistry of marine water and sediments. Berlin, Germany: Springer-Verlag.

Hedges JI and Keil RG. 1995. Sedimentary organic matter preservation: an assessment and speculative synthesis. Mar Chem 49: $81-115$.

Hess LL, Melack JM, Novo EMLM, et al. 2003. Dual-season mapping of wetland inundation and vegetation for the central Amazon Basin. Remote Sens Environ 87: 404-28.

Humborg C, Mörth C-M, Sundbom M, et al. 2010. CO $\mathrm{CO}_{2}$ supersaturation along the aquatic conduit in Swedish watersheds as constrained by terrestrial respiration, aquatic respiration and weathering. Global Change Biol 16: 1966-78.

Johnson MS, Lehmann J, Riha SJ, et al. 2008. $\mathrm{CO}_{2}$ efflux from Amazonian headwater streams represents a significant fate for deep soil respiration. Geophys Res Lett 35: L17401, doi:10.1029/ $2008 \mathrm{gl034619.}$

Kennedy M, Droser M, Mayer LM, et al. 2006. Late Precambrian oxygenation: inception of the clay mineral factory. Science 311: $1446-49$.

Lal R. 2003. Soil erosion and the global carbon budget. Environ Int 29: 437-50.

Lehner B and Döll P. 2004. Development and validation of a global database of lakes, reservoirs and wetlands. J Hydrol 296: 1-22.
Lovett G, Cole J, and Pace M. 2006. Is net ecosystem production equal to ecosystem carbon accumulation? Ecosystems 9: 152-55.

Marotta H, Duarte CM, Sobek S, and Enrich-Prast A. 2009. Large $\mathrm{CO}_{2}$ disequilibria in tropical lakes. Global Biogeochem Cy 23: GB4022, doi:10.1029/2008gb003434.

Mayorga E, Aufdenkampe AK, Masiello CA, et al. 2005. Young organic matter as a source of carbon dioxide outgassing from Amazonian rivers. Nature 436: 538-41.

Oh NH and Raymond PA. 2006. Contribution of agricultural liming to riverine bicarbonate export and $\mathrm{CO}_{2}$ sequestration in the Ohio River basin. Global Biogeochem Cy 20: GB3012, doi:10.1029/2005GB002565.

Ometto J, Nobre A, Rocha H, et al. 2005. Amazonia and the modern carbon cycle: lessons learned. Oecologia 143: 483-500.

Prigent C, Papa F, Aires F, et al. 2007. Global inundation dynamics inferred from multiple satellite observations, 1993-2000. J Geophys Res 112: D12107, doi:10.1029/2006JD007847.

Pritchard DW. 1952. Salinity distribution and circulation in the Chesapeake Bay estuarine system. J Mar Res 11: 106-23.

Raymond PA and Oh NH. 2009. Long term changes of chemical weathering in rivers heavily impacted from acid mine drainage: insights on the impact of coal mining on regional and global carbon and sulfur budgets. Earth Planet Sc Lett 284: 50-56.

Raymond PA, Oh NH, Turner RE, and Broussard W. 2008. Anthropogenically enhanced fluxes of water and carbon from the Mississippi River. Nature 451: 449-52.

Richey JE, Melack JM, Aufdenkampe AK, et al. 2002. Outgassing from Amazonian rivers and wetlands as a large tropical source of atmospheric $\mathrm{CO}_{2}$. Nature 416: 617-20.

Schlünz B and Schneider RR. 2000. Transport of terrestrial organic carbon to the oceans by rivers: re-estimating flux- and burial rates. Int J Earth Sci 88: 599-606.

Smith SV and Hollibaugh JT. 1993. Coastal metabolism and the oceanic organic carbon balance. Rev Geophys 31: 75-89.

Sobek S, Tranvik LJ, and Cole JJ. 2005. Temperature independence of carbon dioxide supersaturation in global lakes. Global Biogeochem Cy 19: GB2003, doi:10.1029/2004GB002264.

Stallard RF. 1998. Terrestrial sedimentation and the carbon cycle: coupling weathering and erosion to carbon burial. Global Biogeochem Cy 12: 231-57.

Stephens BB, Gurney KR, Tans PP, et al. 2007. Weak northern and strong tropical land carbon uptake from vertical profiles of atmospheric $\mathrm{CO}_{2}$. Science 316: 1732-35, doi:10.1126/science.1137004.

Syvitski JPM, Vorosmarty CJ, Kettner AJ, and Green P. 2005. Impact of humans on the flux of terrestrial sediment to the global coastal ocean. Science 308: 376-80.

Takahashi T, Sutherland SC, Wanninkhof R, et al. 2009. Climatological mean and decadal change in surface ocean $\mathrm{pCO}_{2}$, and net sea-air $\mathrm{CO}_{2}$ flux over the global oceans. Deep-Sea Res Pt II 56: 554-77.

Thomas H, Schiettecatte LS, Suykens K, et al. 2009. Enhanced ocean carbon storage from anaerobic alkalinity generation in coastal sediments. Biogeosciences 6: 267-74.

Tranvik LJ, Downing JA, Cotner JB, et al. 2009. Lakes and reservoirs as regulators of carbon cycling and climate. Limnol Oceanogr 54: 2298-314.

Van Oost K, Quine TA, Govers G, et al. 2007. The impact of agricultural soil erosion on the global carbon cycle. Science 318 : 626-29.

Waldbusser GG, Voigt EP, Bergschneider H, et al. 2010. Biocalcification in the eastern oyster (Crassostrea virginica) in relation to long-term trends in Chesapeake Bay pH. Estuar Coast, doi:10.1007/s12237-010-9307-0.

Waterloo MJ, Oliveira SM, Drucker DP, et al. 2006. Export of organic carbon in run-off from an Amazonian rainforest blackwater catchment. Hydrol Process 20: 2581-97.

Wilkinson BH and McElroy BJ. 2007. The impact of humans on continental erosion and sedimentation. Geol Soc Am Bull 119: 140-56. 